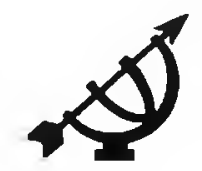

\title{
Conflicting belief systems: some implications for education
}

\author{
E.J. van Niekerk \\ Department Secondary School Teacher Education \\ Faculty of Education \\ University of South Africa \\ PRETORIA \\ E mail: vniekej@alpha.unisa.ac.za
}

Abstract

Conflicting belief systems: some implications for education

In this article the conceptions of knowledge and time within Christianity, secular humanism and traditional African religion are juxtaposed. In order to emphasise the vital role of belief systems in the field of education, some educational implications are inferred from these different conceptions of knowledge and time. The need to create enough space within the South African education system so that parents will be able to send their children to schools where education is conducted according to their particular belief systems is also foregrounded.

\section{Introduction}

The three most important belief systems influencing education philosophy and thus also educational practice in South Africa are traditional African religion, secular humanism and Christianity. Conflicting belief systems are manifested in different and conflicting cosmologies, anthropologies, philosophies and pedagogies.

In the field of education the influence of belief systems is inter alia manifested in conceptions of knowledge, conceptions of time, standards of education, attitudes towards discipline, learning styles, and so forth. In this article the first two of the above-mentioned will be discussed in relation to their significance for education. As this is a comprehensive theme for an article the focus will only be on the most important aspects, avoiding the particulars of the matter. There is a vast body of literature that interested readers can consult on the detailed particulars of these matters. 
On the basis of a literature study the conflicting conceptions of knowledge and time of the three relevant belief systems are juxtaposed in this article. Thereafter an attempt is made to use this exposition, as well as the ideas of Fowler (1980, $1987,1990,1997)$, in order to derive some educational implications of these views of knowledge and time.

Academics, and others, sometimes overlook the important role that religious motives play in human history, cultural formation and in education. There is no neutral education; all education is governed by belief systems of one kind or the other (Dreckmeyr, 1997:10). The purpose of this article is to explore the vital role that South Africa's leading belief systems play in education.

\section{Conflicting conceptions of knowledge}

\subsection{The Christian view of knowledge}

Christianity is a system of truth enveloping the entire cosmos and all aspects of human life (Noebel, 1993:30). The idea that the authority of God's Word should be acknowledged in all spheres of life, including the field of science, was advanced particularly during the Protestant Reformation (Ouweneel, 1997:16). The Word, that is Biblical revelation, as the central principle of knowledge is the foundation of the totality of Christian life, both in its practical and scientific activity. The Word - Biblical revelation - is therefore taken as the point of departure and the religious basic motive of science. The radical and central Biblical theme, namely creation, fall into sin and redemption by Jesus Christ as the incarnate Word of God, is the central spiritual motive behind all Christian thought (Dooyeweerd, 1968:42, 132; Kalsbeek, 1975:63-66). This religious basic motive should inspire Christians in such a way that it becomes a formative socio-cultural power and a formative factor in human cultural development (Dooyeweerd, 1968:33-34).

The Bible teaches that God is the extracosmic originator of all truth, be it religious or scientific. Thus scientific truth relates to its religious foundation. Because God is the origin and source of all that exists, religious and scientific knowledge should be a unified and meaningful whole. The unity of all knowledge should be upheld, despite the fact that the knowledge explosion brought about a division of knowledge into disciplines and subjects during the last two hundred years. The meaningful unity of knowledge means that faith and knowledge should not be separated into two domains, the former belonging to a domain divorced from reason and the latter belonging to the domain of reason and science where human reason is regarded to be autonomous and the only source of authoritative knowledge. Furthermore, the unity of knowledge means that true knowledge should lead to commitment and action and cultural formation in accordance with a Biblical life and world view (Dreckmeyr, 1997: 26-30; Spier, 1979:25-27). 
In Christian thought science can be described as an attempt to discover God's created lawful order, that is the totality of laws, principles, norms and rules that apply to the created world order and which God kept intact despite the human fall into sin. Facts derive their true meaning from the created order of reality, which humans are able to know from God's revelation in nature and in the Bible (Ouweneel, 1997:44, 51; Kalsbeek, 1975:64-66). God's lawful ordering of human existence and creation as a whole sets boundaries to human action. Besides these determinant conditions God has also set normative conditions for human actions that cover the whole range of our relationships with creation. These normative conditions are revealed in Scripture, but in order to translate them into normative action we must also carefully investigate creation itself (Fowler, 1980:47-48). Without the perspective of faith that only the Bible can give all examination of creation will, however, produce only a distorted picture of the world (Fowler, 1987:213).

According to Christian belief true knowledge is possible because of the real, objective existence of the structure and order that God created. Christian scholars should realise, however, that human knowledge is subjective and that true knowledge depends on the proper use of our God-given cognitive abilities. True knowledge always points to God (Dreckmeyr, 1997:26-28). Scientists should therefore use their God-given logical and empirical research abilities within the context of the wisdom of divine revelation. Human reason was also affected by the fall into sin, and therefore it should be subjected to the Word of God. In spite of the wonderful abilities of human reason as a gift from God, all scientific endeavour is only provisional and open to alteration (Ouweneel, 1997:14-18). Humans can never know everything there is to know.

To a Christian nature is neither a sacred domain (as primal societies believe), nor a neutral terrain (as humanists believe). God has revealed Himself in nature, which is a part of His creation. Humans, who are created in God's image, are appointed to exercise stewardship over nature (see Psalm 8). Such stewardship implies responsibility towards God and fellow humans. The Christian goal of acquiring scientific knowledge is responsible action and a dominion which controls the environment for the good, and not for the autonomous mastery thereof (Fowler, 1990:79-80). In the Christian perspective, nature is amenable to human governance and cultural development, but this should be done in such a manner that it remains true to the created order of reality (Smith, 1988:107-108).

The Reformation's grounding of modern science (described above), which in fact allowed modern science to emerge (Hodgson, 1997), is accepted by scientists who practise science within the Christian world view. The Biblical grounding of science has, however, in general been lost sight of - due to the secular humanism that the spirit of the Renaissance and Enlightenment engendered (Ouweneel, 1997:67). 


\subsection{The secular humanist view of knowledge}

In secular humanist scientific practice the supra-natural sphere is denied because it is incompatible with secularism's own religious basic motive, which assumes that the law for knowing is situated within the human knower. Secular humanists believe that human reason functions in a self-sufficient and autonomous way. True knowledge, they believe, can be obtained through observation, experimentation and rational analysis and does not point to God, but to the human individual autonomous knower. This belief is a product of the process of secularization that started with the Renaissance and freed human reason from the bonds of church and divine revelation (Schoeman, 1975:28-29; Dooyeweerd, 1968:66; Fowler, 1987:27-33).

Secular humanist scientific endeavour is driven by two central religious motives, namely nature and freedom, which are actually in polar opposition to each other. The scholastic, dualistic Thomistic religious motive of nature and grace, which divides world and life into a secular and sacred realm, paved the way for the introduction of these secular humanist religious motives of nature and freedom. In secular humanist scientific practice the "nature" part of the scholastic motive is retained, but the "grace" or sacred part is replaced with humanistic freedom. Having denied all belief in a supra-natural sphere, modern humanists have since the Renaissance sought infinite possibilities in nature which would satisfy their creative impulses (Dooyeweerd, 1968:35-36, 44-47, 64-65). Modern thought is also characterised by the dichotomy between the nature and freedom poles of the dialectic secular humanist religious ground motive (Fowler, 1980:28-42).

The autonomy of human reason that secular humanists assume cannot provide a common basis to the different secular humanist paradigms and philosophical trends. There is no encompassing philosophical framework unifying secular humanist scientific practice; thus knowledge cannot be presented as a unity. Various philosophical frameworks exist instead, for example positivism, rationalism, pragmatism and existentialism (Van Niekerk, E.J., 1995). The positivistic movement has been the dominant stream throughout the nineteenth and twentieth century and it has been known by names such as empiricism, neopositivism, logical positivism, logical empiricism, analytic philosophy, etc. (Fowler, 1980:30). Each of the -isms in secular humanist thought originate from the absolutising of one specific scientific viewpoint which considers empirical reality only from one fundamental aspect of human experience. Thus each -ism is an attempt to reduce all other aspects of human experience to modalities of the absolutized aspect. Such absolutization of one specific aspect of reality is usually followed by a reaction in the opposite direction in order to present a more balanced perspective (by placing more emphasis on an aspect that has previously been neglected). The result is a seemingly never-ending chain of reactions (Schoeman, 1988:189; Dooyeweerd, 1968:20, 84). 
The de-sacralization of nature under the influence of Christianity made science possible, also secular humanist science. In secular humanist thought nature is seen as an uncreated, self-generated neutral terrain that humans can control through natural science. The Christian idea of a given world-order, founded in divine creation, was incompatible with the humanist religious motive. The humanist religious motive of nature and freedom implied that humanity should regard itself as the sole ruler of its own destiny and of the world, both of which would be ruled through science, especially natural science. By absolutizing human ability, everything was subjected to the human craving to dominate and control (Smith, 1988:105-106; Dooyeweerd, 1968:64-66).

The humanist faith in humanity and in the power of human reason to rule the world and to elevate man to a higher level of freedom and morality has proved a failure and has now been relegated to the era of modemity. Modernity has, however, left its mark on Western civilization. It destroyed the belief in absolute Biblical truth and strong Christian faith and thereby led to the relativism (Dooyeweerd, 1968:175) nowadays labelled post-modernism. The secular humanist religious ground motives of nature and freedom are re-interpreted in post-modernist thought, and though rationalism is criticised in post-modernist thought, the idea of the autonomy of human reason is still upheld (Ouweneel, 1997:18).

\subsection{The traditional African view of knowledge}

The most important religious motive in the lives of traditional Africans is to fit harmoniously into the traditional order for life which is rooted in traditional religious views. This motive implies that the cosmological structure of supernatural outside influences which determine traditional life must be kept in harmonious balance. Maintaining the harmony in the cosmos is regarded as a human obligation. Fitting into the order for life further implies fitting into the community into which one is born (which includes one's deceased ancestors). All important rituals and ceremonies have a communal character. The principle of conforming to the community includes conforming to the deceased members because it is believed that as ancestral spirits they can influence the lives of the living and even cosmic powers, and they should therefore always be respected Finally, traditional Africans strive to fit harmoniously into the inevitable cyclical course of time. This aspect will be dealt with in the next section. The African approach to life can thus be summarized as the acceptance of the existing traditional order (Coertze, 1985:12-13, 19; De Beer, 1996:15-19; Van Niekerk, A., 1996:3, 12-13, 25; Gyekye, 1996:4, 17). The knowledge necessary to fit into the traditional order for life is traditionally, communally and religiously determined and sanctioned. It is a closed system of knowledge in which the needs of primal society, tradition, conformity and the various specialists in the primal society (such as tribal leaders, diviners, traditional doctors, etc.) play the leading part. 
In African thought consciousness is not self-consciousness, but consciousness of the flow of life in the community and the world. Precedence is given to the common good of the community to which the individual owes his/her existence. Knowledge is embodied in the ancient traditions of the community which are handed down from generation to generation. Care is taken that everyone acquires the minimum knowledge and standards set for proper functioning in every stage of life. Learning is a group activity and care is taken that there are no failures in African communities. Traditional African culture clings to those aspects that bind communities together and harmony, unity and uniformity are cherished. The group has an overwhelming influence on African consciousness. The longing to conform and agree is cherished more than discursive rationality and innovation. African culture is intolerant of heresy and difference. It focuses on harmony, unity of thought and action, the protection and perpetuation of the community, and a reaffirmation of past traditions of the community. African traditional society dictates what, when and how to think. Myth, ritual, particular beliefs and group harmony supersede reason. The totalitarian rule of the community does not allow the individual to elevate himself above and beyond the community, and forecloses the emergence of any knowledge, unless such knowledge is sanctioned by the group (Sono, 1994:1-20; Tedla, 1995:30-31; Mbiti, 1976:108-109).

African culture embraces tradition and continuity and is thus past oriented. Even production (hunting and agriculture) is done according to tradition. The learning of obedience and compliance is stressed. Curiosity, initiative, imagination, creativity, experimentation and critical thinking are frowned upon. Traditional forms of indolence, intolerance and belief hamper intellectual development. The West's activism, energy and desire to investigate, control, change and renew are essentially alien to Africa's traditional desire to maintain harmony and balance in the cosmos. The existing order on earth and the great beyond should be maintained unchanged and therefore there is no real future dimension of time and conscious planning for the future as is the case in Western culture. The desired future direction is always the maintenance of the present status quo based on ancient traditions (Sono, 1994:xvi-xviii, 8; Coertze, 1985:12, 18-19; Van Niekerk, A., 1992:5, 17; Van Peursen, 1976:46).

The non-literary mode of thought in traditional African culture has hampered creativity, imagination and initiative. A non-literate culture reflects and stimulates communalism and traditionalism. Literate conditions display patterns of thought and communication unknown in non-literate conditions, such as critical, analytical processes of the mind. In traditional Africa forms of knowledge such as natural science, mathematics and analytical thinking could not germinate nor survive (Sono, 1994:xiii-xix, 1-4). 


\section{Conflicting conceptions of time}

\subsection{The Christian view of time}

Christianity adheres to a linear, rather than a cyclical, view of time which it inherited from the ancient Israelites who lived in anticipation of the coming of the Messiah. Christians believe that God created everything, sustains it and will bring history to a fitting close as described in the Bible. The new humanity will then be the heir to a most glorious eternal future with God (Smith, 1988:108; Noebel, 1993:764-765).

Christians believe that the eternal God involves Himself in our temporal existence through His Scriptural revelation and redemptive action in Christ. Christians therefore share not only in a calling on earth, but also in eternal life. From a Christian perspective no real meaningful answer can be found to the question of man's origin, essential nature and final destination outside of the central Biblical message of creation, fall into sin and redemption through Jesus Christ. According to Biblical revelation there is no future hope for humanity and for the whole process of humanity's cultural development except in Jesus Christ as the pivot of human history and His kingdom as the ultimate end of worldhistory (Dooyeweerd, 1968:111-112).

Christians should actively participate in history in order to direct the course of history to the honour of their Creator. Humans have been endowed by God with the vocation and freedom to control nature, to take part in the process of cultural formation and thus to serve God. The historical process of cultural development is a normative human vocation committed to humanity at its creation. Norms are given as principles which should acquire form in accordance with the level of historical development of a society. Christianity must, therefore, assume a sociocultural form in history so that it may be a formative power in human society and in societal institutions, such as schools, industrial communities, states, etc. (Raath, 1997:93-94; Dooyeweerd, 1968:33-34, 91-92, 98-105; Smith, 1988:98; Spier, 1975:37).

From a Christian perspective the historical development of humanity entails the development of its formative power over the world and over societal life. Humans should discover the possibilities that God has provided in creation. In this regard scientific enterprise plays an important part. In the process of cultural evolvement the undifferentiated mode of existence, found in primal societies, is substituted with a differentiated societal structure. Because of human sinfulness and the absolutization of that which is relative, the process of cultural evolvement is marked by conflict. There is no mention of a future earthly paradise in Scripture (Dooyeweerd, 1968:91, 98-99, 102-105, 110-11; Smith, 1988:98, 107-108; Kalsbeek, 1975:137-150). 
Conflict bellef systems: some implications for education

\subsection{The secular humanist view of time}

Secular humanism adheres to a linear conception of time, which it inherited from Christianity. It is, however, a secularized linear conception of time. Secular humanists believe that humans are autonomous rational beings and masters of their own destiny. This belief emerged during the Renaissance, which was a religious movement aiming at the transformation of Christianity into a religion of secular humanism. The central Biblical theme of creation, fall into sin and redemption through Christ was reinterpreted in terms of the humanistic freedom motive that regards humans as being masters of their own destiny and of the world. Because humanity was cut loose from the transcendental conceptions of Christianity, new explanations for the origin, meaning and destiny of life were propounded in line with the secular humanist conception of time and thereby the process of secularization was set in motion (Van Niekerk, E.J., 1992:140-141; Dooyeweerd, 1968:64-66; Van den Berg, 1995:24-25, 37, 193, 201; Smith, 1988:106; Schoeman, 1988:22-23)

Having emancipated themselves from all belief in a supra-natural sphere, secular humanists viewed the surrounding world/nature from the optimistic viewpoint of their own expectations of the future. Everything was subjected to the desire to dominate in order to realise future worldly ideals. Discoveries in the field of natural science strengthened the confidence in humanity's own rational abilities to realise an idealised future. The idea of continual, linear progress in history became the foundation of the secular humanist development model that has since exercised a major influence, not only in the West, but also globally. Many secular ideologies, such as liberalism, capitalism, nationalism, socialism and communism function in close alliance with this Western model of development. According to this model the pursuit of progress, development and the improvement of the quality of life is defined relatively narrow in terms of materialistic values (Dooyeweerd, 1968:47; Smith, 1988:89, 106).

According to the above secular humanist perspective, which is that of modernism, the basic ingredients of history are spontaneous generation, evolution and an optimistic expectation of a future utopia on earth. Humanists are optimistic about the future because of their faith in evolutionary theory. In the absence of any belief in the existence of God the earthly progress of humanity becomes the only meaningful goal. In radical historicism humans are completely enclosed in their earthly temporal existence without any possibility of attaining a supra-historical level of contemplation (Noebel, 1993:722, 725727; Dooyeweerd, 1968:62)

The modernist conception of time, which takes as its point of departure humanity's progress and emphasises humanity's potential, is at present being questioned. Post-modemists are suspicious of the so-called master-narratives of modernism, such as the model of continual progress in history. Post-modernist 
historical analysis emphasises contingency and discontinuity (Van Niekerk, E.J., 1996). This can be regarded as a reaction towards the freedom pole of the dialectic secular humanist religious motive of nature and freedom.

\subsection{The traditional African view of time}

For an African time is a composition of events which have occurred, which are presently occurring and which are about to occur in the immediate future. The long-range future conception of time that Westerners hold is virtually absent because events which are embedded in the future have not occurred and therefore do not constitute time. Viewed from a Western perspective traditional Africa operates with a two-dimensional view of time that has an extensive past and a present into which the virtually absent future is incorporated. The micro or present dimension of time has a sense of immediacy. It is the period of conscious living that binds individuals and their immediate environment together. Macro-time (the great past) overlaps micro-time, and the latter disappears into the former. Events that have taken place move backwards from micro-time into macro-time beyond which nothing can proceed. Everything finds its destination in the macro period which is the final storehouse of all phenomena and events. It is the period of myth which gives a sense of foundation binding all created things together. The foundation of the present is also embedded in macro-time (Mbiti, 1976:16-23).

Traditional Africans adhere to a cyclical view of time. There is no end to the circular movement of birth, marriage, reproduction, death, moving into the domain of the ancestors after death, and finally into the domain of the spirits This circularity is also reflected in the passing of the seasons. History and prehistory are dominated by myth, but there is no myth about the end of the world because in the cyclical conception of time there is no end to time. Time follows a fixed circular course and humans are subject to this. Time is not manipulated or accelerated or regarded as a scarce commodity as is the case in Western societies (Smith, 1988:101; Mbiti, 1976:19, 24; Van Niekerk A., 1996:3, 8-9 Boon, 1996:17).

In the African conception of history time proceeds neither towards a future utopia (as some humanists believe) nor to the end of the world (as Christians believe). Africans believe that the future does not hold anything radically different either from the present (micro-time) or from the past (macro-time). Traditional Africans believe that past, present and future are basically the same in the sense that tradition is the sole foundation of the future. In this sense that the future is bound to tradition and the past, traditional Africa is conscious of the future. African people do not believe in upward progress through human achievement. Africa does not plan for a distant future nor does Africa dream of utopia. As has already been indicated, Africa is traditionally past-oriented and 
preoccupied with retaining the status quo (Mbiti, 1976:23; Coertze, 1985:18-19; Van Niekerk, A., 1996:42).

In African thought humans who have died move gradually from micro-time to macro-time. When a person dies he/she becomes part of the "living dead" until such time that he/she is not remembered by any living person. At that time the journey to the world of the spirits is fully accomplished. Being remembered and honoured by their offspring after death is considered most important by Africans, because only in this way can a safe and gradual passage to the world of the spirits be assured. This is why procreation is so important to Africans. If the "living-dead" are suddenly forgotten they are excommunicated from the micro-time period, of which they are considered to still form a part, and they are turned into a state of non-existence. Africans perceive no dichotomy between the visible and invisible worlds which they believe are connected by the cycles of birth and death. There is believed to be constant communication between these worlds, and the relation between the living and deceased is one of solidarity, communication and reciprocity. African religious activities are therefore chiefly focused on the relationship between living humans and their departed ancestors whereby each person tries to project him/herself into the world of what remains of him/her after death (Mbiti, 1976:25-27; Tedla, 1995:26; Van Niekerk, A., 1996:103).

African people encountered the Western (Christian and secular humanist) future dimension of time and a differentiated societal mode of existence through Christian missionary teaching, Western education and the invasion of modern technology. The accommodation of this future dimension of time into African thought is, however, not a smooth process. The African world view is tenacious and is not easily exchanged for Western views (Mbiti, 1976:27-28, 216-217; Van Niekerk, A., 1992).

\section{Educational implications}

Conflicting ground motives are manifested in different conceptions of knowledge and time which have specific implications for education. In this section some of the educational implications of these conflicting ground motives are discussed. The discussion is based on the analysis thus far as well as an extension thereof using mostly the ideas of Fowler $(1980,1987,1990,1997)$. The focus will only be on the most general educational implications. (The vast literature on the precise nature of Christian, secular humanist and African education will not be taken into account.) The implications of traditional African and secular humanist views of knowledge and time will only be discussed briefly, while more attention will be given to the implications of Christian views of knowledge and time for Christian schooling. 


\subsection{Some implications of a traditional African view of knowledge and time for education}

In the following exposition the implications of traditional African views of knowledge and time (paragraphs 2.3 and 3.3) are discussed in relation to the Western formal education system which Africa has adopted.

Western knowledge, conceptions of time and educational institutions (of a Christian and secular humanist nature) are alien to traditional Africa. Traditional African conceptions of knowledge and time are not reconcilable with the Westem views of knowledge and time which are propounded in formal education. In this regard the alienating effect of a foreign education system which was transplanted to Africa from Europe during colonial times, without real adaptation to African culture, should be kept in mind. Authors such as Fuller (1991), Tedla (1995), Van Niekerk (1996:51-59) and Fowler (1997:176207) are acutely aware that Africa's accommodation of Western institutions like formal education is problematic, since these are undergirded by presuppositions which are in conflict with traditional African ground motives.

Traditional Africa does not need the Western education system for the maintenance of its primal mode of civilisation. It does, however, need formal education to become integrated into a technologically developed mode of civilisation. The traditional African views of knowledge and time are in conflict with technological development and will therefore have a negative influence on Africa's adaptation to development/modernisation. The thought processes valued in traditional Africa run counter to those which are required for successful functioning in a technologically developed society and its education system. This is the dilemma of African education today. Sifuna (1990:15) and Fowler (1997:203) suggest, however, that neither traditional African nor modern education be abandoned in their entirety, but that an unique blending thereof suitable for present educational circumstances in Africa be considered by African communities.

It will, however, not be possible to adapt Western educational institutions to traditional African conceptions of knowledge and time whilst at the same time retaining their Western character and function. Hence concepts such as Africanize and Africanization should be applied to formal education in a discerning manner. Africanization cannot entail a wholesale return to the traditional way of education, but useful aspects of Africa's cultural and educational heritage should nevertheless be retained while adapting to modern conditions.

The traditional conception of time hampers Africa's integration into a developed mode of civilisation with its differentiated societal structure. Africa's full adaptation to a linear time conception is a radical change that will span 
generations and it will not be an easy process. The change from a cyclical to a Western, linear conception of time with its dynamic future dimension will be particularly difficult because of the unrealistic expectations of the future that emerge. Those Africans who have relinquished the age-old cyclical view will want to share in the so-called benefits/privileges that development has brought (such as formal education), but they must be willing to equally share the accompanying responsibilities as well.

Although Africa was introduced to the formal education system of the Western world by missionaries, the dominant life and world view of contemporary formal education is secular humanism. Africa thus finds itself within the sphere of influence of the traditional African, Christian and secular humanist ground motives. What the outcome of these conflicting ground motives will be in education is not certain at this stage. If the present situation in South Africa can be taken as a cue, it seems as if secular humanism has obtained the dominant position.

\subsection{Some implications of a secular humanist view of knowledge and time for education}

The most basic implication of secular humanism for education is that schools are regarded as secularised institutions in which the whole ethos and every aspect of the education system/school is governed by humanistic principles. Modern humanistic religion is not identified by religious confessions of faith, but by the humanistic principles that give direction to human activity and the societal institutions of the modern world. This can be illustrated with reference to the view of knowledge governing our schools. Secular humanism assumes that the law which governs human knowing is situated within the human knower. This assumption which permeates modern educational practice is a secular humanist religious presupposition which has a decisive effect on the way children are brought up in modern schools (Fowler, 1987:27, 29, 33, 189).

In the modern world schooling is valued primarily for the power it is thought to give humans to master their environment. Mastery is therefore regarded as the supreme value in the learning process. Low priority is consequently given to learning that, though it promotes understanding, does not enhance learners' ability for power and control (Fowler, 1990:70-71, 77-78). Fowler (1990:53) states the following in this regard

The dominant world view of Western society includes the belief in the progressive human conquest of nature through progress in autonomous knowledge. As a result innovation and expansion in knowledge in order to increase the powers of human control over nature is highly valued as a life value in Western society. This translates into the educational value that gives priority to the kind of knowledge that facilitates this autonomous control over the environment, particularly scientific and mathematical knowledge 
Children are taught to optimise human freedom through the rational (scientific and technological) control of nature. Humanity is seen as the master of its own destiny and therefore education should contribute towards the maximalisation of optimal conditions of life. Progress through mastery (the exercise of autonomous power) is emphasised and therefore humanists hold that everybody should be involved in the Western model of development through education

In secular humanist belief the meaning of the world that we experience through our senses is to be found within human experience. Even though God may be allowed a place on another level of existence that complements and provides an ultimate explanation for the existence of the world, this other level does not affect the meaning of the world in itself (Fowler, 1990:41). In line with the dualistic ground motive of nature and freedom, we find in secular humanist thought both rationalistic ideas of meaning as an a priory given that can be fully discovered by human reason alone and irrationalist ideas of meaning as originating in the free human personality (Fowler, 1980:45). No attention is given to questions about the source of order and meaning in modern secular schooling, since the secular model of science teaching assumes that such questions do not exist (Fowler, 1990:25-26). In contemporary schooling subjects are taught as self-contained systems with procedures and concepts whose meanings are wholly defined by the system. Meanings are adopted as part of the hidden curriculum. Thus secular schooling is uncritical at this most fundamental level because it simply assumes the basis of meaning (Fowler, 1990:25, 76). The meaning of life, cultural development and human history is thus uncritically taught in terms of secular systems like evolutionism, pragmatism, materialism and the other -isms of secular thought.

It is in the atmosphere of warfare between rationalism and irrationalism, arising from the religious dialectic between nature and freedom that is at the root of modern thought, that education must find its way. The swing of the pendulum between the nature and freedom pole of the humanistic religious ground motive is evident in education in the battle between conservatism that wants to uphold a rationalistic content-centred orientation in education on the one side and pragmatism and the so-called progressive, learner-centred education on the other (Fowler, 1980:30-42). This dialectic is evident also in the educational debate in South Africa surrounding the new Curriculum 2005.

In spite of the tremendous expansion in knowledge, secular humanist thought struggles with the problem of integrating the meaning of insights and distinguishing true from false theories. Knowledge falls apart into bits and pieces - knowledge that humanists try to integrate into a meaningful whole, but without much success. There seems to be no meaningful context for the integration of knowledge, a problem which arises from the dialectic ground motive underlying all modern secular humanist thought (Fowler, 1980:47). As a result attempts are made to integrate knowledge either in terms of the secular 
humanist philosophy which is dominant at that time or by exposing children to various secular humanist -isms that emphasise either the nature or freedom pole of the secular humanist ground motive.

\subsection{Some implications of a Christian view of knowledge and time for education}

In the Reformational world view life is seen as a whole with faith as its single guiding principle. Faith in this view leads the Christian life in its totality in every area and dimension, including educational theory and practice. Christian education is therefore a comprehensive practice that is shaped by the Christian faith as its most basic motive. The Christian imperative in education calls Christians to an educational practice that is integral to a whole, undivided life of obedience to Biblical principles. Such obedience forbids an educational practice that divorces so-called earthly relationships and societal structures from the Christian's relationship to God. Christian educational theory must therefore be submitted to Biblical revelation since education can be authentically Christian only as the Christian religious principle directs the whole educational enterprise (Fowler, 1987:7, 10, 86, 211). The Christian community should build and apply a Christian philosophy of education that is firmly rooted in the Biblical religious motive (Fowler, 1980:28-42).

Christian education cannot be achieved through a synthesis with other views of knowledge and time as this would lead to a type of education which is merely flavoured with a Christian additive. For the same reason Christian education can also not be achieved in conjunction with old or new educational theories which are rooted in an idolatrous religious commitment/belief system. Secular humanist values should therefore be replaced by sound educational values in harmony with Biblical revelation. Sound Christian educational theory and practice is impossible if Christians accept the division of life and the world into two realms, namely secular and religious, natural and supernatural, material and spiritual. Such division rules out any possibility of a distinctively Christian educational practice. In contrast to the dialectic religious ground motive of nature-grace and nature-freedom the Christian motive of creation, fall into sin and redemption through Jesus Christ leads to an integrated view of life and the world. This motive should form the pre-theoretical basis of Christian educational thought (Fowler, 1980:28-42, 44; 1987:14-15, 183-184; 1990:54-55).

Christian schooling should be based on a Christian understanding of the role and function of the school as societal institution. The cultural mandate to shape the God-given creation includes the authority to organise societal institutions like the school which should be given shape and form according to Biblical principles for communal relationships. Christian education cannot be achieved by adding a Christian curriculum to the secular humanist idea of what the school is (Fowler, 1987:87, 120; 1990:64). 
If and when Christian schooling is characterised by the formative influence of the Christian faith shaping the whole educational practice, learners will become aware of the connection between Christian faith and the education programme. The teaching-learning activity will be governed by the Christian religious motive in a comprehensive way. All subjects will be taught from a Christian perspective. The educative role of the school is to deepen the learner's understanding of creation. The most fundamental Christian presupposition concerning creation is that all things are created by God and for God so that they exist only in God, and therefore all knowledge is religious in character. The normative function of the Word of God applies to all human cultural activity in the economic, social, jural, aesthetic and all other aspects of creation. In school the learner's experience of creation should therefore lead to an understanding of the functioning of the various aspects of creation. Such experience of creation will have educative value if it gives maximum opportunity for the learner to exercise control over creation, gives insight into creational law, enlarges the learner's experience of creation, is enlightened by the Word of God and enables the learner to experience himself/herself as a creature in community. The relevance of Christian religion for knowledge in all subjects and the teachinglearning activity as a whole should therefore be acknowledged in Christian education (Fowler, 1987:10, 97, 119-125; 1980:49).

Creation in its totality is ordered and governed by the Word of God. Creation cannot therefore be divided, as secular thought tries to do, into an impersonal nature sphere governed by impersonal laws and a world of human creation governed by the human will and/or reason. A valid theory must be a faithful response to the created order of the world which Christians know was ordered by God's Word as its law. Cut off from the Word of God humans cannot integrate the meaning of their insights gained from a study of creation, nor can they distinguish true from false theories. Integrative knowledge comes from a faith response to revelation in the incarnation, in the Scriptures and in the ordering of all things. This is taught to children by drawing their attention to the revelatory encounter with God in all experience, an encounter that demands response. It is taught by challenging learners to examine their own response and by enabling them to recognise idolatrous responses in intellectual and/or scientific theories and in daily experience. The integrating function of a Christian cosmology should assist learners in experiencing knowledge as a meaningful unity. Various knowledge systems should be related to one another in the teaching-learning situation and to the given reality of creation. Learners should be guided to recognise the fact that they are learning about one multifaceted but unitary creation (Fowler, 1990:24-25, 65, 91, 101; 1980:47).

The development of children's God-given cognitive abilities should receive due attention in Christian schooling, but in such a way that it is not absolutised at the expense of other aspects of humanity. Christian schooling will aim at achieving 
fullness of humanity, expressed in faithful relationships with God, neighbour and the environment. Therefore, attention will also be given to emotional expression, aesthetic development, physical development, moral norms, and enriching interpersonal relationships. Christian education will extend the experience of learners as widely as possible because the Word of God that orders the world guarantees the integrity of our experiences. Science is a valid activity in man's task of unfolding creation, but science should not be absolutised as the only source of knowledge. Biblical revelation is also a source of knowledge. Learning should therefore be directed towards the integral development of the child for his/her religious calling in life, understood in the broad Christian meaning thereof (Fowler, 1987:13-14; 1980:50, 57).

Prosperous stewardship, which should be at the heart of Christian educational endeavours, pertains to the submission of everything in the world, including our human abilities, to the God whose world it is. In such a learning environment provision will be made for the different kinds of gifts and abilities of learners and each learner will be helped to develop his/her particular talents for fruitful service as cultural developers of God's creation. Assessment will therefore not focus on mastery of concepts and skills alone, but also on how these have been integrated into a Christian response and responsible action (Fowler, 1987:16, 72; 1990:85-87). Human response to God's Word in the Bible and in creation requires discernment, understanding and decision. Learners should be assisted to correctly discern the order that God's Word gives to creation and to make decisions in a believing response to that Word in their calling of obedient cultural formation in all spheres of life (Fowler, 1987:200)

\section{Conclusion}

The purpose of the article, as stated in the introduction, was to juxtapose the most important belief systems in South Africa and some of their educational implications in order to reveal the vital role that belief systems play in education. Much of the conflict prevalent in education in South Africa today, as well as the past strife and the inevitable future strife are the direct and indirect consequences of the conflicting belief systems in South African society and education. Therefore one can conclude that the greatest problem/challenge facing authorities in the post-1994 education dispensation is to create sufficient space/freedom within the education system for the various belief systems, so that children will be educated according to their parents' life and world view. The exposition in this article revealed that not all belief systems can be reconciled with or accommodated to one another. Christianity certainly cannot be reconciled to other belief systems and still be true to itself. South African educationists and policy makers should pay due attention to this important matter, in order to facilitate communication and responsible decision-making. 
The educational debate in South Africa should be extended to include debate about the fundamental issue of religious ground motives that pertains to educational theory and practice. It appears at this stage that a war of words on the merits and demerits of the old and new educational system is raging, but that the fundamental matter of religious ground motives is not taken into account. Religious presuppositions underlying educational theory and practice should be taken into account consciously, otherwise there is a real danger of educational debates becoming superficial. It is especially the task of Christian educationists to reveal all underlying religious ground motives.

\section{Bibliography}

BOON, M 1996. The African way. The power of interactive leadership Sandton : Struik. COERTZE, R.D. 1985. Kulturele implikasies van identiteitsontplooiing (In Du Toit, S.I., red. Menswees in die kollig. Pretoria : NG Kerkboekhandel p. 5-25.)

DE BEER, F.C. 1996. Livelihoods from resource flows. Conference paper: Linköping congress, Sweden, 19-22 August.

DRECKMEYR, T. 1997. Towards Christ-centred education Pretoria CcE Books.

DOOYEWEERD, H. 1968. In the twilight of Western thought Nutley, N.J. : Craig Press.

FOWLER, S. 1980 Issues in the philosophy of education. Potchefstroom : PU for CHE

FOWLER, S. 1987. Christian educational distinctives. Potchefstroom : PU for CHE

FOWLER, S. ed 1990. Christian schooling: education for freedom. Potchefstroom PU for CHE

FOWLER, S. 1997. Reality, knowledge and African education: in the context of a postmodernist world. (In Higgs, P., Miedema, S., Van der Walt, J.L. \& Zecha, G. ed Postmodernism and education. Potchefstroom : PU for CHE. p. 176-207.)

FULLER, B. 1991. Growing up modern. The Western state builds Third-World schools. New York : Routledge.

GYEKYE, K. 1996. African cultural values An introduction. Philadelphia/Accra : Sancofa

HODGSON, P. 1997. The Christian origin of science (The first Goyne lecture on theology and science.) Oxford : Corpus Christi College.

KALSBEEK, L. 1975. Contours of a Christian philosophy. Toronto : Wedge

MBITI, J.S 1976. African religions and philosophy. London : Heinemann.

NOEBEL, D A. 1993. Understanding the times. Summit Press : s.l.

OUWENEEL, W.J. 1997. Wijs met de wetenschap. Heerenveen : Barnabas

RAATH, A.W.G 1997. Die aard en aanbieding van Geskiedenis as 'n vakdissipline (In Stoker, P H. \& Gerber, J.M., red. Voed hulle op Bloemfontein : VCHO p. 76-101.)

SCHOEMAN, P.G. 1975. Grondslae en implikasies van 'n Christelike opvoedingsfilosofie. Bloemfontein : Sacum.

SCHOEMAN, P.G 1988. Wysgerige pedagogiek Pretoria : Sacum

SIFUNA, D N. 1990. Development of education in Africa: the Kenyan experience Nairobi : Initiatives Publishers.

SMITH, H J 1988. Sosiologie vir die ryksburger - 'n kennismaking. Bloemfontein : VCHO.

SONO, T. 1994. Dilemmas of African intellectuals in South Africa. Pretoria : University of South Africa.

SPIER J M. 1979. Oriëntering in die Christelike wysbegeerte Bloemfontein : Sacum.

TEDLA, E. 1995 Sankofa. African thought and education. New York : Peter Lang

VAN DEN BERG, J.H. 1995. Metabletica van God. Kapellen : Pelckmans

VAN NIEKERK, A 1992. Sáám in Afrika. Kaapstad : Tafelberg

VAN NIEKERK, A. 1996. Anderkant die reënboog Kaapstad : Tafelberg. 
VAN NIEKERK, E.J. 1992. 'n Temporaliteitspedagogiese ontleding en evaluering van die globaliseringsverskynsel Pretoria : Universiteit van Suid-Afrika. (D. Ed -proefskrif.)

VAN NIEKERK, E.J. 1995. The rise and manifestation of globalism and its implications for science. Koers, 60(1) 89-102

VAN NIEKERK, E.J 1996. Enkele aspekte van die postmodernistiese kritiek teen die modernisme en die relevansie daarvan vir die opvoedkunde. Suid-Afrikaanse Tydskrif vir Opvoedkunde, 16(4):210-215.

VAN PEURSEN, C.A. 1976. Cultuur in stroomversnelling Amsterdam/Brussel : Elsevier 